\title{
Branding Produk Sebagai Solusi UMKM di Masa Pandemi
}

\author{
Ginanjar Abdurrahman ${ }^{1 *}$, Victor Wahanggara ${ }^{2}$ \\ 1,2 Jurusan Teknik Informatika, Universitas Muhammadiyah Jember \\ ${ }^{1}$ abdurrahmanginanjar@unmuhjember.ac.id , ${ }^{2}$ victorwahanggara@unmuhjember.ac.id
}

\begin{abstract}
Corona Virus Disease (Covid-19) has a big impact and becomes an obstacle to various sectors of Indonesian economy, especially MSMEs. Product Product branding is one solution for MSMEs to have economic resilience during the Covid-19 Pandemic. The solution proposed in the community service this time is to provide additional insight to partners (MSMEs) about product branding. The solution provided is an activity that provides knowledge and insight for MSMEs in knowing and understanding product branding as a solution for MSMEs, especially during the Covid-19 pandemic, so that MSMEs can survive during the Covid-19 Pandemic. This community service activity was carried out in the form of a webinar using the Google meet platform with 10 participants consisting of the owner of the MSME Kedai Susu Mas Happy / Fresh Milk Drinks and their staff. The webinar activity was carried out with the presenters presenting a presentation on Product Branding for 30 minutes, followed by discussions with participants. The enthusiasm of the participants towards the material was very good, which was indicated by the intensity of the questions and answers that occurred during the activity. As a result of PKM activities, MSMEs gain knowledge related to product branding as a provision in dealing with the Covid-19 Pandemic, so that MSMEs know the right way to market products, are right in ordering, are easily recognized, and have loyal customers. Evaluation of this activity can be seen from the participants' understanding of the material based on the increase in the posttest score which is quite significant compared to the pretest value. The pretest score with the lowest score is 60 and the highest score is 67, while the posttest score with the lowest score is 76 and the highest score is 92.
\end{abstract}

Keywords : branding, product, msme, pandemic, covid-19

\begin{abstract}
Abstrak
Corona Virus Disease (Covid-19) memiliki dampak besar dan menjadi hambatan terhadap berbagai sektor ekonomi Indonesia, khususnya UMKM. Branding produk merupakan salah satu solusi untuk UMKM agar memiliki ketahanan ekonomi di masa Pandemi Covid-19. Solusi yang diajukan dalam PKM Stimulus kali ini adalah memberikan tambahan wawasan kepada mitra (UMKM) tentang branding produk. Solusi yang diberikan merupakan kegiatan yang memberikan pengetahuan dan wawasan bagi UMKM dalam mengetahui dan mengerti branding produk sebagai solusi untuk UMKM khususnya pada masa pandemi Covid19, sehingga UMKM dapat bertahan di masa Pandemi Covid-19. Kegiatan pengabdian masyarakat ini dilaksanakan dalam bentuk webinar menggunakan platform Google meet dengan 10 orang peserta yang terdiri dari pemilik UMKM Kedai Susu Mas Happy/Minuman Susu Segar beserta staf nya. Kegiatan webinar dilaksanakan dengan pemateri memaparkan presentasi tentang Branding Produk selama 30 menit, dilanjutkan dengan diskusi dengan peserta. Antusiasme peserta terhadap materi sangat baik yang ditunjukkan dengan intensitas tanya jawab yang terjadi selama kegiatan berlangsung. Hasil kegiatan PKM, UMKM mendapatkan pengetahuan terkait branding produk sebagai bekal dalam menghadapi Pandemi Covid-19, sehingga UMKM mengetahui cara tepat memasarkan produk, tepat dalam pemesanan, mudah dikenal, dan mempunyai customer setia. Evaluasi kegiatan ini dapat dilihat dari pemahaman materi peserta berdasarkan peningkatan nilai posttest yang cukup signifikan dibandingkan nilai pretest. Adapun nilai pretest dengan nilai terendah 60 dan nilai tertinggi 67, sedengkan nilai posttest dengan nilai terendah peserta yakni 76 dan nilai tertinggi peserta mencapai 92 .
\end{abstract}

Kata Kunci : branding, produk, umkm, pandemi, covid-19 


\section{PENDAHULUAN}

Eksistensi UMKM yang sangat banyak menjadikan UMKM sektor usaha yang diharapkan mampu meningkatkan ekonomi di era persaingan bebas dan agar bisa bertahan menghadapi krisis ekonomi global (Lubis \& Junaidi, 2016). Dengan demikian, diharapkan bisa tercapai ketahanan ekonomi suatu negara.

Ketahanan ekonomi adalah keuletan dan ketangguhan bangsa dalam mengembangkan kekuatan nasional untuk menghadapi ancaman dari dalam maupun luar negeri, baik secara langsung maupun tidak langsung untuk menjamin keberlangsungan perekonomian negara yang sangat dinamis (Marlinah, 2017). Salah satu ancaman besar dalam dunia ekonomi yang sekarang terjadi adalah Corona Virus Disease 2019 (Covid-19).

Sejak bulan Maret 2020, Corona Virus Disease 2019 (Covid-19) mulai masuk ke Indonesia. Pertumbuhan dan penyebaran virus ini hingga tanggal 17 November 2020 mengalami kenaikan yang cukup signifikan yang dapat dilihat pada grafik kasus baru pada Gambar 1. Seiring pertumbuhan virus tersebut, covid-19 memiliki dampak yang besar dan menjadi hambatan terhadap berbagai sektor ekonomi Indonesia khususya UMKM. Menurut (Putra, 2020) hasil surveri ADB $50 \%$ UMKM Gulung Tikar Akibat Pandemi Covid-19 karena omset turun sekitar $40 \%$ - $70 \%$.

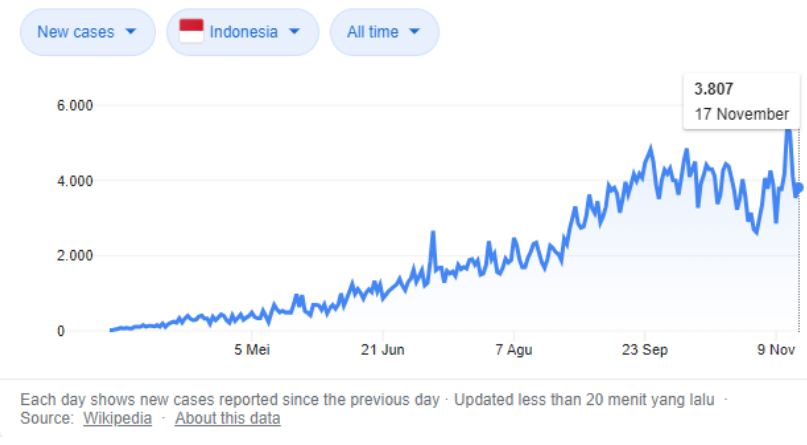

Gambar 1. Grafik kasus baru Covid-19

Branding produk merupakan salah satu solusi yang ditawarkan untuk UMKM agar memiliki ketahanan ekonomi di masa pandemi Covid-19. Menurut Kortler dan Gertner (Diarta, Lestari and Dewi, 2017) brand dapat membedakan produk yang satu dengan yang lainnya, selain itu juga memberikan nilai pada suatu produk.
Dalam hal ini, brand bisa meningkatkan rasa yakin seseorang terhadap suatu produk. Sedangkan menurut Boomsma \& Arnoldus (Diarta, Lestari and Dewi, 2017) brand dibuat untuk membuat calon konsumen percaya kualitas, reliabilitas, status sosial, nilai dan keamanan suatu produk. Simmons (Diarta, Lestari and Dewi, 2017), menyatakan bahwa brand suatu produk atau jasa harus dapat menciptakan hubungan yang kuat antara produk atau jasa dengan pelanggan. Menurut (Wijaya; Zendy Tedja, 2013).

Dalam konsep branding tidak hanya membuat target pemasaran memilih suatu produk di dalam pasar yang penuh kompetisi, tetapi juga membuat prospek-prospek pemasaran melihat brand (merek) suatu produk sebagai satu-satunya. Dengan adanya branding produk, diharapkan UMKM dapat dengan mudah dalam memasarkan produknya, melakukan pemesanan produk yang tepat, produknya mudah dikenal konsumen, serta konsumen akan setia (loyal).

\section{METODE}

Kegiatan pengabdian masyarakat ini dilaksanakan dalam bentuk webinar yang dilaksanakan dengan menggunakan media google meet. Kegiatan ini dimulai dari sosialisasi program menggunakan flyer yang diinfokan melalui grup whatsap UMKM di Jember. Alur kegiatan dilaksanakan dengan ; (1) registrasi peserta, (2) pembacaan curriculum vitae narasumber, (3)pemaparan materi oleh narasumber, serta (4) diskusi narasumber dengan peserta kegiatan

Tabel 1. Tahapan Kegiatan PKM

\begin{tabular}{|c|l|l|}
\hline No & \multicolumn{1}{|c|}{ Kegiatan } & \multicolumn{1}{c|}{ Sub Kegiatan } \\
\hline 1. & $\begin{array}{l}\text { Sosialisasi Program } \\
\text { Kegiatan }\end{array}$ & Sosialisasi program kegiatan \\
\hline 2 & $\begin{array}{l}\text { Pelaksanaan } \\
\text { Kegiatan }\end{array}$ & $\begin{array}{l}\text { Pemaparan materi dan diskusi } \\
\text { mengenai Branding Produk } \\
\text { sebagai solusi di masa pandemic. }\end{array}$ \\
\hline 3 & Pembuatan Laporan & $\begin{array}{l}\text { Pembuatan Laporan pelaksanaan } \\
\text { kegiatan }\end{array}$ \\
\hline
\end{tabular}

\section{HASIL DAN PEMBAHASAN}

Pada kegiatan ini, peserta yang berasal dari UMKM diharapkan mempunyai pengetahuan tentang konsep 
branding produk, sehingga dapat bertahan di masa Pandemi Covid-19. Kegiatan ini dilaksanakan pada hari Sabtu, tanggal 19 April 2021 dimulai dari jam 09.00 11.00 yang diikuti oleh 10 peserta. Acara dimulai dengan registrasi peserta, jam 8.45 yang kemudian dilanjutkan dengan pembacaan curiculum vitae pemateri. Kemudian, pemateri memaparkan presentasi tentang Branding Produk selama 30 menit, dilanjutkan dengan diskusi dengan peserta kegiatan. Pada awalnya dibuka 2 sesi pertanyaan dengan satu sesi diberikan kesempatan 3 penanya. Peserta menyambut diskusi dengan antusias. Setelah 2 sesi pertanyaan, masih ada yang ingin mengajukan pertanyaan, sehingga dibuka lagi 1 sesi pertanyaan dengan memberikan kesempatan kepada 2 penanya. Hasil kegiatan PKM, UMKM mendapatkan pengetahuan terkait branding produk sebagai bekal dalam menghadapi Pandemi Covid-19, sehingga UMKM mengetahui cara tepat memasarkan produk, tepat dalam pemesanan, mudah dikenal, dan mempunyai customer setia.

Kegiatan pengabdian masyarakat ini dilaksanakan dalam bentuk webinar menggunakan platform Google meet dengan 10 orang peserta yang terdiri dari pemilik UMKM Kedai Susu Mas Happy/Minuman Susu Segar beserta staf nya. Kegiatan webinar dilaksanakan dengan pemateri memaparkan presentasi tentang Branding Produk selama 30 menit, dilanjutkan dengan diskusi dengan peserta. Antusiasme peserta terhadap materi sangat baik yang ditunjukkan dengan intensitas tanya jawab yang terjadi selama kegiatan berlangsung. Hasil kegiatan PKM, UMKM mendapatkan pengetahuan terkait branding produk sebagai bekal dalam menghadapi Pandemi Covid-19, sehingga UMKM mengetahui cara tepat memasarkan produk, tepat dalam pemesanan, mudah dikenal, dan mempunyai customer setia.

Hasil evaluasi peserta terkait pemahaman materi disajikan dengan skala nilai antar (0-100) terhadap 10 peserta. Evaluasi yang dilakukan dalam dua tahapan, yakni pretest (sebelum materi disampaikan) dan posttest.(setelah materi disampaikan). Hasil pretest dan posttest ditampilkan pada Gambar 2 dan Gambar 3 sebagai berikut :
Evaluasi Kegiatan Peserta Pengabdian Kepada Masyarakat Branding Produk



Gambar 2. Hasil Pretest dan Posttest Peserta

Dari hasil evaluasi terlihat bahwa pemahaman awal peserta terhadap materi sudah cukup baik. Hal ini terlihat dari hasil pretest peserta dengan nilai terendah 60 dan nilai tertinggi 67 . Pada hasil posttest terlihat peningkatan yang cukup signifikan jika dibandingkan dengan hasil pretest peserta. Hal ini dapat dilihat dari nilai terendah posttest peserta yakni 76 , nilai tertinggi peserta mencapai 92.

Kegiatan pengabdian kepada masyarakat ini diharapkan tidak berhenti sampai di sini, tetapi perlu dilaksanakan secara berkesinambungan khususnya pada masa pandemi seperti sekarang ini, sehingga dapat memotivasi para pelaku usaha untuk tetap bertahan dalam situasi ekonomi yang terpengaruh pandemi covid-19.

Adapun dokumentasi kegiatan disajikan pada Gambar 3 sampai Gambar 5

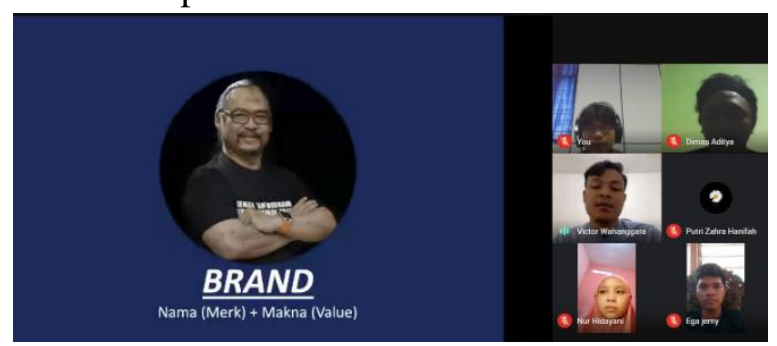

Gambar 3. Dokumentasi kegiatan

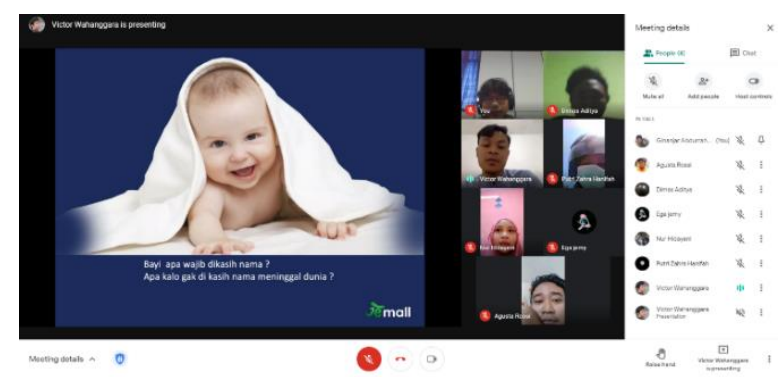

Gambar 4. Dokumentasi kegiatan 


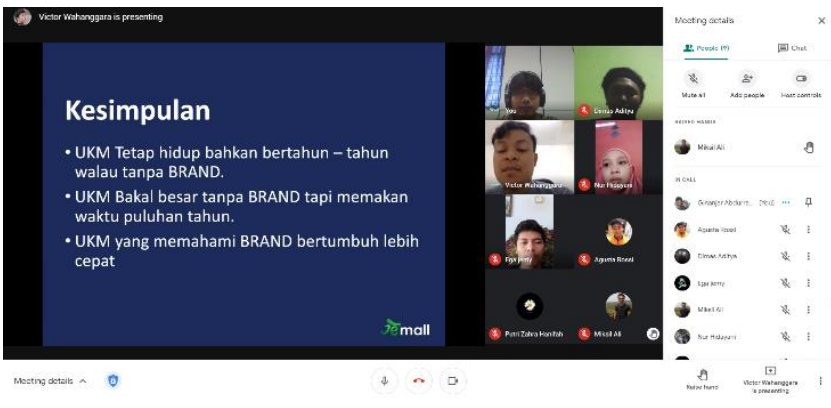

Gambar 5. Dokumentasi kegiatan

\section{KESIMPULAN}

Dari hasil evaluasi terlihat bahwa pemahaman awal peserta terhadap materi sudah cukup baik. Hal ini terlihat dari hasil pretest peserta dengan nilai terendah 60 dan nilai tertinggi 67. Pada hasil posttest terlihat peningkatan yang cukup signifikan jika dibandingkan dengan hasil pretest peserta. Hal ini dapat dilihat dari nilai terendah posttest peserta yakni 76 , nilai tertinggi peserta mencapai 92

Antusiasme peserta yang mengikuti kegiatan pengabdian kepada masyarakat ini tinggi. Hal ini ditunjukkan dengan intensitas tanya jawab yang terjadi selama kegiatan berlangsung,

\section{UCAPAN TERIMA KASIH}

Ucapan terima kasih kami tujukan untuk LPPM Universitas Muhammadiyah Jember yang telah mendukung dalam pelaksanaan kegiatan pengabdian kepada masyarakat khususnya dukungan berupa dana kegiatan pada kegiatan ini

\section{DAFTAR PUSTAKA}

Diarta, I., Lestari, P. and Dewi, I. (2017) 'Strategi Branding dalam Promosi Penjualan Produk Pertanian Olahan PT. Hatten Bali untuk Pasar Pariwisata Indonesia', JURNAL MANAJEMEN AGRIBISNIS (Journal Of Agribusiness Management), 4(2), pp. 170-187.

Marlinah, L. (2017) 'Meningkatkan Ketahanan Ekonomi Nasional Melalui Pengembangan Ekonomi Kreatif', Managemen Informatika AMIK BSI Bekasi, XVII(2).

Nurfriani, V. et al. (no date) 'Analisis Kinerja Usaha Mikro, Kecil dan Menengah ( UMKM ) Dengan dan Tanpa Pinjaman Di Kabupaten Jember ( Analysis Performance of
Micro , Small and Medium Enterprise ( SMEs ) With and Without Loans in Jember Region )', pp. 1-5.

Putra, D. A. (2020) 'imbas-pandemi-50-persen-umkm-gulungtikar-akibat-pandemi-covid-19@ww.merdeka.com'. kompas.com, p. 2. Available at: https://www.merdeka.com/uang/imbas-pandemi-50persen-umkm-gulung-tikar-akibat-pandemi-covid19.html? page $=2$.

Wijaya; Zendy Tedja (2013) 'Penyusunan dan Implementasi Strategi Branding Produk Kuliner dalam Membentuk Brand Knowledge sebagai Oleh-Oleh Khas Kabupaten Madiun (Studi Deskriptif Kualitatif Mengenai Penyusunan dan Implementasi Strategi Branding Brem "Tongkat Mas" dalam Membentuk Bra'. 